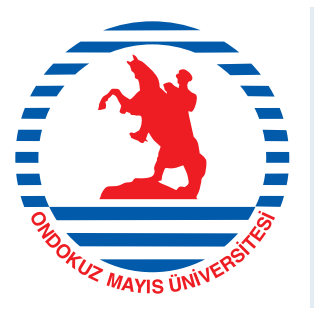

Journal of Experimental and Clinical Medicine

Deneysel ve Klinik Tip Dergisi

Klinik Araştırma / Clinical Research

doi: $10.5835 /$ jecm.omu.29.02.007

\title{
Psoriaziste sistemik tedavilerin etkinliklerinin immünohistokimyasal metodla karşılaştırılması
}

\author{
Comparison of the efficacy of the systemic treatments by immunohistochemical method in psoriasis \\ Günseli Şefika Pancar *, Fatma Aydınª Levent Yıldız ${ }^{\mathrm{b}}$, Esra Pancar Yüksela ${ }^{\mathrm{a}}$, Nilgün Şentürk ${ }^{\mathrm{a}}$, Tayyar Cantürkª, \\ Ahmet Yaşar Turanlı ${ }^{a}$
}

Ondokuz Mayıs Üniversitesi, Tıp Fakültesi, ${ }^{a}$ Dermatoloji ve ${ }^{b}$ Patoloji Anabilim Dallarl, Samsun, Türkiye

\begin{tabular}{|c|c|}
\hline \multicolumn{2}{|c|}{ MAKALE BİLGÍLERİ } \\
\hline \multicolumn{2}{|c|}{ Makale geçmişi } \\
\hline Geliş tarihi & $: 13 / 12 / 2011$ \\
\hline Kabul tarihi & $: 26 / 12 / 2011$ \\
\hline
\end{tabular}

\section{* Yazışma Adresi:}

Günseli Şefika Pancar

Tokat Devlet Hastanesi

Dermatoloji Kliniği,

Tokat, Türkiye

e-posta: drgunselisefika@hotmail.com

Anahtar Kelimeler:
Psoriasis
Dar band UVB
Asitretin
Metotreksat
Ki-67 ekspresyonu
Psoriazis şiddet indeksi

Key words:

Psoriasis

Narrow band UVB

Acitretin

Methotrexate

Ki-67 expression

Psoriasis severity index

\section{ÖZET}

Psoriazis kronik, inflamatuar, T hücre aracılı hiperproliferatif deri hastalığıdır. Hastaların \% 20-30'unun sistemik tedaviye ihtiyaç duymasına rağmen sistemik tedavi modalitelerinin etkinliklerinin birbirleri ile karşılaştırıldığı çalışmalar az sayıdadır. Dar band ultraviyole B (UVB), asitretin ve metotreksat y1llardır geleneksel tedaviler olarak kullanılmaktadır. $\mathrm{Bu}$ tedavilerin etkinliklerinin, psoriasis şiddet indeksi (PASI) ve proliferasyon marker ekspresyonu olan Ki 67 ile karşılaştırılması amaçlandı. Hastalar dar band UVB (haftada üç gün) alan 13 hasta, asitretin (1 mg/kg/gün oral) alan10 hasta, metotreksat ( $25 \mathrm{mg} / \mathrm{hafta}$ intramusküler) alan 11 hasta olmak üzere üç gruba ayrıldı. Tedavi öncesi ve tedavinin 3 . ayında PASI ve biyopsi değerlendirilmesi yapıldı. PASI ve immünohistokimyasal Ki 67 ekspresyonundaki azalma üç tedavi grubunda da istatistiksel olarak anlamlıyd $1(p<0,001)$. Fakat gruplar arasında istatistiksel farklılık yoktu $(\mathrm{p}>0,05)$. İyileşme oranı PASI'de Ki 67 ekspresyonundan istatiksel olarak daha yüksek bulundu. Dar band UVB, asitretin ve metotreksat tedavilerinin etkinlikleri açısından klinik ve immünohistokimyasal olarak birbirlerine üstünlüklerinin olmadığı tespit edildi. Fakat bu sonuçlar gösterdi ki klinik iyileşme (PASI), immünohistokimyasal hücre proliferasyonu ile birebir korelasyon göstermediğinden tedavi periyodunun belirlenmesinde baş rol oynamamalıdır. J. Exp. Clin. Med., 2012; 29:117-120

\begin{abstract}
Psoriasis is a chronic, inflammatory, T cell mediated hyperproliferative skin disease. Although the disease requires systemic treatment in about $20 \%-30 \%$ of psoriatic patients, studies about the comparison between the efficacy of the systemic treatment modalities are few. Narrowband ultraviolet B (UVB), acitretin and methotrexate are being used as traditional treatments for years. It is aimed to compare the efficacy of these common treatments with the psoriasis area and severity index (PASI) and Ki 67 which is a marker expresses proliferation. Patients were divided into three groups; 13 patient who received narrowband UVB (3 days a week), 10 patient who received acitretin $(1 \mathrm{mg} / \mathrm{kg} /$ day oral) and 11 patient wo received methotrexate ( $25 \mathrm{mg} /$ week intramuscular), PASI and biopsies were assessed before and at the third month of the treatment. The reduction in the PASI and immunohistochemically Ki 67 ekspressions, were statistically significant in three treatment groups $(\mathrm{p}<0.001)$. But results were not statistically different between groups $(p>0.05)$. Clearence rate was found statistically higher in PASI than Ki 67 ekspression. We conclude that efficacy of narrowband UVB, asitretin and methotrexate therapies did not have any predominance to each other clinically and immunohistochemically. But these results showed that clinical improvement (PASI) may not play a significant role in determining therapy period because it is not correlated directly with cell proliferation immunohistochemically.

J. Exp. Clin. Med., 2012; 29:117-120
\end{abstract}

(C) $2012 \mathrm{OMU}$

\section{Giriș}

Psoriazis, keskin sınırlı, eritemli plak veya papüller üzerinde yerleşmiş parlak, sedefi-beyaz skuamlarla karakterize, kronik seyirli, inflamatuvar bir hastalıktır (Barker, 
2001). Hastalığın etyopatogenezinde immünolojik, otoimmün ve genetik faktörlerin etkili olduğu düşünülmektedir.

Hastalığın yaşam boyu sürmesi, kesin tedavisinin olmaması, yaşam kalitesini olumsuz yönde etkilemesi nedeniyle birçok tedavi ajanı kullanılmaktadır. Hastalık şiddetinin ve tedaviye yanıtın belirlenmesinde klinik olarak en çok psoriasis şiddet indeksi (PASI) skoru kullanılmaktadır (Barker, 2001). Son y1llarda tedavilerin etkinliklerinin histopatolojik olarak değerlendirilmesinde ise $\mathrm{Ki} 67$ ve p53 gibi gen ekspresyonları kullanılmaktadır (Başkan ve ark., 2001; Barut ve ark., 2011). Psoriazis tedavisinde s1k kullanılan sistemik tedavi ajanlarının immünohistokimyasal olarak farklılıklarını ortaya koyan çalışmalar az sayıdadır (Hannuksela-Svahn ve ark., 1999; Chen ve ark., 2001; Apa ve ark., 2005; Ceović ve ark., 2006). Bu çalışmada, PASI değerleri ve immünohistokimyasal metodla psoriazis için sık kullanılan sistemik tedavilerin (dar bant ultraviyole (UVB), asitretin ve metotreksat) etkinliklerinin karşılaştırılması amaçlanmıştır.

\section{Gereç ve yöntem}

$\mathrm{Bu}$ çalışmaya 2005-2008 yılları arasında Ondokuz Mayıs Üniversitesi Dermatoloji Kliniğine başvuran, klinik olarak psoriasis tanısı alan ve sistemik tedaviye ihtiyaç duyan 34 hasta alındı. Tedavi öncesi her hastadan tam kan sayımı, karaciğer, böbrek fonksiyon testleri ve akciğer grafisi istendi. On sekiz yaşından küçükler, gebe ve emzirme dönemindekiler, karaciğer ve böbrek fonksiyon testlerinde bozukluğu olanlar, kanser tanısı alanlar, kemoterapi veya radyoterapi tedavisi verilenler, kullanılan ilaçlara karş1 bilinen duyarlılığı, sistemik enfeksiyonu olanlar çalışmaya alınmadı. Şiddetli psoriasis, eritrodermik psoriasis, PASI skorunun \% 10'nun üzerinde olması, yaşamı tehdit eder tipte püstüler psoriasis, topikal tedavilere dirençli psoriasis olguları sistemik tedaviye başlama endikasyonları olarak belirlendi. Çalışmaya başlanmadan önce etik kurul onayı alındı. Hastaların PASI'ları hesaplandı ve deri biyopsileri (4 mm punch) alınd1. Hastalar 3 gruba ayrıld1. Grup 1 (13 hasta, haftada üç seans dar bant UVB), Grup 2 (10 hasta, neotigason avidin biotin yöntemi ile Ki 67 primer antikoru ve üniversal boyama kitleri kullanılarak immünohistokimyal çalışma yapıldı. Nükleer boyanmalar pozitif boyanma olarak kabul edildi. Ki 67 indeksi hesaplanırken epidermiste yer alan 1500 adet keratinosit içerisinde pozitif boyananlar sayıldı ve Ki 67 indeksi 1500 hücrede pozitif boyanan hücre sayıs1 cinsinden ifade edildi. Tedavi öncesi ve tedavinin 3. ayındaki PASI skorları ve Ki 67 ile pozitif boyanan hücre sayısı önce gruplar içinde daha sonra da gruplar arasında karşılaştırıldı. Bu karşılaştırma, iyileşme yüzdeleri hesaplanarak da yapıldı. Ayrıca PASI ve immün boyama sonucundaki iyileşme yüzdeleri birbiri ile karşılaştırıldı. Bu çalışmada verileri değerlendirmek üzere istatistiksel analizlerde aritmetik ortalama \pm standart sapma, paired $\mathrm{t}$ test ve Kruskal Wallis analiz yöntemleri kullanıldı. Tüm istatistiksel testlerde $\mathrm{p}<0,05$ anlamlı olarak kabul edildi.

\section{Bulgular}

Çalışmaya alınan 34 hastanın 18'i erkek ve 16'sı kadın olup, yaşları $(41,0 \pm 3,1)$; yaş ortalaması $8-45$ arasında değişmekteydi.

Grup 1 (4 erkek 9 kadın, yaş ortalaması 34,3 $\pm 4,3$ min-mak; 18-66)

Grup 2 (7 erkek 4 kadın, yaş ortalaması 49,5 $\pm 4,4$ min-mak; 27-72)

Grup 3 (5 erkek 5 kadın, yaş ortalaması 40,3 $\pm 6,8$ min-mak; 18-74)

Her üç grup arasında cinsiyet ve yaşları arasında istatiksel olarak fark yoktu $(\mathrm{p}>0,05)$. Her üç tedavi grubunda tedavi öncesi ve sonras1, PASI ve immünohiskimyasal Ki 67 ekspresyonunda istatistiksel olarak anlamlı azalma tespit edildi $(\mathrm{p}<0,001)$. Üç tedavi grubunun birbiri ile karşılaştırılması sonucunda, tedavi öncesi ve sonrası PASI ve immünohistokimyasal Ki 67 ekspresyonları açısından istatistiksel olarak anlamlı fark bulunmadi $(\mathrm{p}>0,05)$ (Tablo 1). Her tedavi grubunda PASI ve immünohistokimyasal olarak Ki 67 ekspresyonunda tedavi öncesi ve sonrası azalma yüzdesi istatistiksel olarak anlamlı iken $(p<0,05)$, tedavi grupları karşılaştırıldığında PASI ve immünohistokimyasal

Tablo 1. Her üç tedavi yönteminin tedavi öncesi-sonrası ve gruplar arası PASI ve immünohistopatolojik Kİ-67 ekspresyonlarının karşılaştırılması

\begin{tabular}{|c|c|c|c|c|c|c|c|}
\hline \multirow{2}{*}{$\begin{array}{l}\text { Hasta Grupları } \\
\text { (n:hasta say1sı) }\end{array}$} & $\begin{array}{c}\text { PASI } \\
\text { TÖ }\end{array}$ & $\begin{array}{l}\text { PASI } \\
\text { 3.ay }\end{array}$ & \multirow[t]{2}{*}{$\mathbf{P}$} & $\begin{array}{c}\text { Ki-67 } \\
\text { TÖ }\end{array}$ & $\begin{array}{c}\text { Kİ-67 } \\
\text { 3.ay }\end{array}$ & $\mathbf{p}$ & \multirow{2}{*}{$\begin{array}{l}\text { Gruplar } \\
\text { arasinda }\end{array}$} \\
\hline & \multicolumn{2}{|c|}{ Ortalama \pm standart sapma } & & \multicolumn{3}{|c|}{ Ortalama \pm standart sapma } & \\
\hline Grup 1 (n: 13) & $11,8 \pm 1,6$ & $4,0 \pm 1,6$ & $\mathrm{p}<0,01$ & $111,7 \pm 7,5$ & $65,0 \pm 9,8$ & $\mathrm{p}<0,01$ & \\
\hline Grup 2 (n: 11) & $10,6 \pm 2,1$ & $3,4 \pm 0,9$ & $\mathrm{p}<0,01$ & $100,9 \pm 12,2$ & $61,5 \pm 10,7$ & $\mathrm{p}<0,01$ & $\mathrm{p}>0,05$ \\
\hline Grup 3 (n: 10) & $9,4 \pm 1,9$ & $2,1 \pm 0,6$ & $\mathrm{p}<0,05$ & $99,4 \pm 9,1$ & $60,6 \pm 10,3$ & $\mathrm{p}<0,05$ & \\
\hline
\end{tabular}

* Sayılan 1500 keratinosit içinde Ki-67 ile boyanan hücre sayısı

TÖ: Tedavi öncesi

$1 \mathrm{mg} / \mathrm{kg} /$ gün oral) ve Grup 3 (11 hasta, metotreksat $25 \mathrm{mg} /$ hafta intramüsküler) tedavisi başlandı. PASI değerlerinin hesaplanması ve immünohistopatolojik inceleme tedavinin 3 . ayında tekrarlandı.

Çalışmaya alınan biyopsi \% 10'luk tamponlanmış nötral formalinde 12-24 saat tespit edildi. Rutin gecelik doku takip işleminden geçirilen doku örneklerinin parafin blokları hazırland. Parafin bloklardan alınan 4-6 mikrometrelik kesitler hematoksilen-eozin ile boyandi.

Adezif pozitif yüklü lamlara alınan doku kesitlerine
Tablo 2. Ki-67 ekspresyonunda ve PASI skorunda azalma yüzdelerinin karşılaştırılması

\begin{tabular}{ccccc}
$\begin{array}{c}\text { Hasta } \\
\text { Grupları }\end{array}$ & $\begin{array}{c}\text { PASI } \\
\text { azalma } \\
\text { Median (min-max) }\end{array}$ & $\begin{array}{c}\text { Ki-67 ekspresyonu } \\
\text { \% azalma }\end{array}$ & P & $\begin{array}{r}\text { Gruplar } \\
\text { arasinda }\end{array}$ \\
\hline Grup 1 & $82,2(16,7-94,7)$ & $41,3(-29,3-83,2)$ & $\mathrm{p}<0,05$ & \\
Grup2 & $77,0(33,3-94,4)$ & $40,9(-15,3-90,6)$ & $\mathrm{p}<0,05$ & $\mathrm{p}>0,05$ \\
Grup 3 & $72,2(-3,57-100,0)$ & $54,0(-205,9-65,4)$ & $\mathrm{p}<0,05$ & \\
\hline
\end{tabular}


olarak Ki 67 ekspresyonu azalma yüzdesi arasında anlamlı fark saptanmamıştır ( $p>0,05)$ (Tablo 2). Her grup içinde PASI ve Ki 67 ekspresyonunda azalma yüzdeleri karşılaştırıldığında PASI'daki azalma daha belirgindi $(\mathrm{p}<0,05)$. Üç aylık tedavi döneminde herhangi bir sebeple tedaviyi kesen olmadı. Yan etkiler sadece grup 3'de gözlendi. Bunlar, 2 hastada geçici alanin aminotransferaz yüksekliği, 1 hastada ise bulantıydı.

\section{Tartışma}

Psoriasis toplumda sik rastlanılan, kronik, tekrarlayıcı bir deri hastalığıdır (Barker, 2001). Psoriasis olgularının $\%$ 20-30'u ise sistemik tedaviye ihtiyaç duymaktadır. Kullanılan tedavi yöntemlerinin hastalar arasında farklı iyileşme düzeylerine neden olması tedavide standardizasyona ulaşmayı güçleştirmektedir. İyileşme düzeylerinde oluşan bu farklılıkların değerlendirilebilmesi için sistemik tedavilerin etkinliklerinin ve birbirlerine üstünlüklerinin bilinmesi gerekmektedir. Fakat tedavi yöntemleri arasındaki etkinlik farklılıklarının ortaya konduğu çalışmalar az sayıdadır. Bu amaçla bu çalışmada sık tercih edilen sistemik ajanlardan dar band UVB, asitretin ve metotreksat tedavilerinin etkinlikleri klinik ve immünohistokimyasal olarak karşılaştırılmıştır.

Literatürde yer alan birçok çalışmada tedavilerin başarısını değerlendirmede yöntem olarak PASI kullanılmıştır. Ki 67 immünohistokimyasal olarak hücre proliferasyonun belirleyicisidir ve son yıllarda tedavilere alınan yanıtın değerlendirilmesinde objektif yöntem olarak histopatolojik Ki 67 ve p 53 gibi gen ekspresyonları kullanılmaktadır (Başkan ve ark., 2001; Barut ve ark., 2011). Psoriatik lezyonel deride özellikle Ki 67'nin normal deriye oranla daha fazla eksprese olduğu bulunmuştur (Apa ve ark., 2005; Ceović ve ark., 2006). Chen ve arkadaşları (2001) psoriaziste klinik şiddetin değerlendirilmesinde immünohistokimyasal marker olan Ki 67'nin alternatif metod olarak kullanılabileceğini göstermişlerdir. Fakat histopatolojik olarak tedaviler arası farklılıkları ortaya konmamıştır (Murray, 1991; HannukselaSvahn ve ark.,1999; Chen ve ark., 2001; Dubertret, 2009). Bu çalışmada da tedaviler arasındaki farklılıkları ve histopatolojik iyileşmeyi değerlendirmede bu metod temel alınarak Ki 67 ekspresyonundaki azalma kullanıldı.

Son yillarda asitretin ve metotreksat tedavilerinin monoterapi olarak etkinliklerine dikkat çekilmektedir (Apa ve ark., 2005; Yazici ve ark., 2005; Ceović ve ark., 2006). Asitretin tedavisinin tek başına etkin olduğu ve hastaların \% 40’ında PASI deki iyileşme oranının \% 90'a ulaştığı, metotreksat tedavisinin ise yaygın psoriaziste etkili ucuz bir yöntem olduğu bildirilmiştir (Dubertret, 2009). Murray tarafından yapılan çalışmada 63 hastada $40-50 \mathrm{mg}$ asitretin tedavisi ile hastaların 12 haftada \% 84 ünde tam veya belirgin iyileşme elde edilmiştir (Murray, 1991). Bir başka çalışmada ise 21 hastanın \% 82,8 inde iyileşme oranı bildirilmiştir
(Akdeniz, 1997). Literatür taramasında tedavi yöntemlerinden elde edilen başarı (tedavi edilen hasta yüzdesi üzerinden) değerlendirildiğinde dar bant UVB için \% 63, \% 73, \% 85 olarak, asitretin için \% 50,1 ve metotreksat için ise \% 85, \% 81 olarak özetlenmiștir (Collins ve Rogers, 1992; Van Greebe-Dooren ve ark., 1994; Al-Sirwaidan ve Feldman, 2000).

Çalışmamızda uygulanan tedavi ajanları ile tedavinin 3. ayında PASI ile etkinlikleri \% 70’leri geçmiş ve tedaviler karşılaştırıldığında iyileşme oranları açısından birbirlerine üstünlükleri bulunmamıştır. Yazıcı ve arkadaşları tarafindan (2005) metotreksat tedavisi ile vakaların \% 90'nında Ki 67 ekspresyonunun azaldığı tesbit edilerek metotreksatın anjiogenez ve proliferasyon üzerindeki başarısından behsedilmiştir. Ceovic ve arkadaşları (2006) psoralen+ultraviyole A(PUVA) tedavisi ile Ki 67 ekspresyonu ve buna paralel keratinosit proliferasyonun azaldığı, PUVA tedavisinin anjiojenik ve antiproliferatif etkisi vurgulanmıştır. Fakat tedaviler arası karşılaştırma yapılmamıştır. Bu amaçla bu çalışmada sık tercih edilen sistemik ajanlardan dar band UVB, asitretin ve metotreksat tedavilerinin etkinlikleri immünohistokimyasal olarak karşılaştırılmıştır. Tedavi öncesi ve sonrası Ki 67 ekspresyonunda azalma her üç tedavi için istatistiksel olarak anlamlı bulundu. Aynı zamanda Ki 67 ekspresyonunun klinik şiddet ve PASI ile paralellik gösterdiği saptandi. Fakat tedavi yöntemleri birbirleri ile karşılaştırıldığında dar band UVB, asitretin ve metotreksat tedavilerinin Ki 67 ekspresyonunu aynı düzeyde etkilediği bulunduvetedavilerarasında farklılıksaptanmadı.Buçalışmada biz üç tedavi yönteminin PASI yanında immünohistopatolojik olarak da (hücre proliferasyon belirteci kullanılarak) etkinliklerini değerlendirerek immünohistopatolojik olarak da farklılıklarının bulunmadığını gösterdik.

Aydın vearkadaşları(2002) tarafından metotreksattedavisi alan 21 hastada yapılan çalışmada klinik iyileşme \% 93 ve histopatolojik iyileşme \% 49 olarak bulunmuştur. Bu nedenle klinik bulgulara bakılarak (PASI ile) tedavi periyodunun belirlenmemesi ve histopatolojik değerlendirmenin yapılmasının önemine dikkat çekilmiştir. Benzer şekilde çalışmamızda, her üç tedavi yönteminde de klinik iyileşmenin histopatolojik iyileşmeye paralel gittiği, ancak PASI'deki iyileşmenin hücre proliferasyonunun göstergesi olan $\mathrm{Ki}$ 67'den daha hızlı olduğu bulunmuştur. Histopatolojik iyileşmenin değerlendirilmesinde daha pratik yöntemlerin bu amaçla araştırılması gerekmektedir. Dar bant UVB, neotigason, metotreksat ajanlarının birbirlerine üstünlükleri bulunamamış ve tedavi periyodunun belirlenmesinde PASI'nin tek başına belirleyici olmaması gerektiği sonucuna varılmıştır. Geniş serilerde ve diğer tedavi yöntemlerini de içine alan araştırmalara gerek duyulmaktadır.

\section{KAYNAKLAR}

Akdeniz, S., 1997. Asitretin ile tedavi edilen psoriasisli hastalarda 3 aylık tedavi sonuçlar1. Turkiye Klinikleri. J. Dermatol. 7, 161-165.

Al-Sirwaidan, S.N., Feldman, S.R., 2000. Clearance is not a realistic expectation of psoriasis treatment. J. Am. Acad. Dermatol. 42 , 796-802.

Apa, D.D., Ikizoglu, G., Api, H., Baz, K., Tasdelen, B., 2005. The changes in expression of ICAM-3, Ki-67, PCNA, and CD31 in psoriatic lesions before and after methotrexate treatment. Arch. Dermatol. Res. 297, 249-255.

Aydın, F., Yıldız, L., Şentürk, N., 2002. Psöriasiste metotreksat etkinliğinin değerlendirilmesinde PASI-histopatolojik skor ilişkisi. Türkderm. $35,110-114$.

Barker, J.N., 2001. Genetic aspects of psöriasis. Clin. Exp. Dermatol. 26, 32-325.

Barut, F., Bektaş, S., Gün, B.D., Bahadır, B., Özdamar, Ş.O., 2011. Psoriazis vulgariste mast hücreleri ve p53 gen ekspresyonu. Türkiye Klinikleri 
J. Med. Sci. 31, 321-327.

Başkan, E.B., Tunalı, S., Filiz, G., Aydoğan, K., Sarıcaoğlu, H., 2001. Psoriasis lezyonlarında Ki-67, PCNA, bcl-2 ve p53 protein ekspresyonlarının immunhistokimyasal yöntemle değerlendirilmesi. Türkiye Klinikleri J. Dermatol. 11, 68-72.

Ceović, R., Pasić, A., Lipozencić, J., Jakić-Razumović, J., Szirovicza, L., Kostović, K., 2006. Antiproliferative, antiangiogenic and apoptotic effect of photochemotherapy (PUVA) in psoriasis patients. J. Eur. Acad. Dermatol. 20, 527-533.

Chen, G..S., Wu, T.M., Yang, S.A., Yu, H.S., 2001. Quantitative assessments of physiological and biological parameters in psoriatic lesions and its correlations to the clinical severity of psoriasis. Kaohsiung J. Med. Sci. 17, 408-418.

Collins, P., Rogers, S., 1992. The efficacy of methotrexate in psoriasis. A review of 40 cases. Clin. Exp. Dermatol. 17, $257-260$.

Dubertret, L., 2009. Retinoids, methotrexate and cyclosporine. Curr. Probl. Dermatol. 38, 79-94.

Hannuksela-Svahn, A., Paakko, P., Autio, P., 1999. Expression of p53 before and after PUVA treatment in psöriasis. Acta Derm. Venereol. 79, 195-199.

Murray, H.E., 1991. A 12-month treatment of severe psoriasis with acitretin: Result of a Canadian open multicenter study. J. Am. Acad. Dermatol. 24, 598-602.

Van Greebe-Dooren, R.J., Kuijpers, A.L.A., Mulder, J., 1994. Methotrexate revisitied: Effects of long term treatment in psoriasis. Br. J. Dermatol. 130, 204-210.

Yazici, A.C., Tursen, U., Apa, D.D., Ikizoglu, G., Api, H., Baz, K., Tasdelen, B., 2005. The changes in expression of ICAM-3, Ki-67, PCNA, and CD31 in psoriatic lesions before and after methotrexate treatment. Arch. Dermatol. Res. 297, 249-255. 